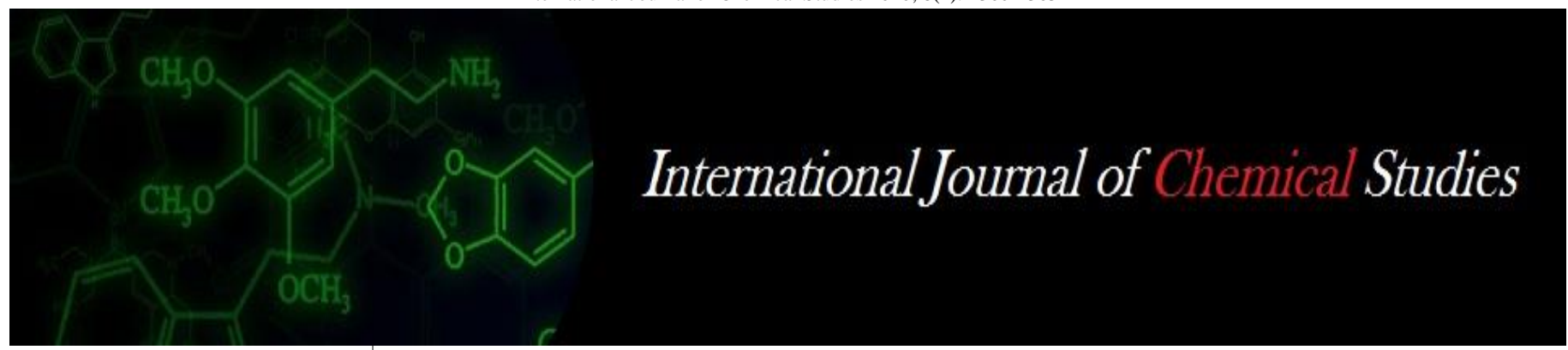

P-ISSN: 2349-8528

E-ISSN: 2321-4902

www.chemijournal.com

IJCS 2020; 8(2): 2360-2363

(C) 2020 IJCS

Received: 10-01-2020

Accepted: 12-02-2020

\section{T Anitha}

Assistant Professor

(Biochemistry), Department of

Postharvest technology,

Horticultural College and

Research Institute, Tamil Nadu

Agricultural University,

Periyakulam, Theni District,

Tamil Nadu, India

\section{R Balakumbagan}

Assistant Professor

(Horticulture), Department of

Vegetable Sciences,

Horticultural College and

Research Institute, Tamil Nadu

Agricultural University,

Periyakulam, Theni District,

Tamil Nadu, India

\section{S Irulandi}

Assistant Professor

(Entomology), Department of

Fruit Crops, Horticultural

College and Research Institute,

Tamil Nadu Agricultural

University, Periyakulam, Theni

District, Tamil Nadu, India

\section{Divyabharathi}

Ph.D., Scholar, Department of Vegetable Sciences, Horticultural College and Research Institute,

Tamil Nadu Agricultural

University, Periyakulam, Theni

District, Tamil Nadu, India

\section{Balamurugan}

Teaching Assistant, Department of Economics, Agricultural College and Research Institute,

Tamil Nadu Agricultural

University, Madurai,

Tamil Nadu, India

Corresponding Author:

T Anitha

Assistant Professor

(Biochemistry), Department of

Postharvest technology,

Horticultural College and

Research Institute, Tamil Nadu

Agricultural University,

Periyakulam, Theni District,

Tamil Nadu, India

\section{Chemical composition of moringa (Moringa oleifera Lam.) leaves from different germplasm}

\author{
T Anitha, $\mathbf{R}$ Balakumbagan, $\mathrm{S}$ Irulandi, $\mathrm{V}$ Divyabharathi and $\mathrm{V}$ \\ Balamurugan
}

DOI: https://doi.org/10.22271/chemi.2020.v8.i2aj.9103

\begin{abstract}
An investigation was carried out in moringa (Moringa oleifera Lam.) to study the extent of genetic variability on yield components and genetic diversity among 12 accessions based on biochemical parameters. The variability persist in the chemical constitutes among the accessions may be due to the persistence of species difference and the prevalence of different agro-climatic conditions. The variation could be also being due to different age and growth phase of the plants. The highest vitamin $\mathrm{C}$ was recorded by PKM MO $2(155.60 \mathrm{mg} / 100 \mathrm{~g})$. Among the genotypes, the highest crude fibre content was observed in PKM MO 1 (25.6 \%). The magnesium content was highest in PKM MO 6 (0.86 \%) followed by PKM MO $12(0.86 \%)$. Potassium content was recorded higher in genotype PKM MO $3(3.86 \%)$, followed by PKM MO 5 (3.20 \%). The accessions PKM MO 7 followed by PKM MO 10 recorded the highest iron content. Thus, this study helped to identify agronomically superior and genetically diverse moringa germplasm accessions that can be utilized in moringa breeding for enhancement of leaf yield and quality.
\end{abstract}

Keywords: Moringa, vitamin C, protein, fibre, potassium and genetic diversity

\section{Introduction}

India is the largest producer of moringa with an annual production of about million tonnes of tender pods. In India, Andhra Pradesh leads in both area (18,000 ha) and production (7, 20,000 MT), followed by Karnataka (12,000 ha and 4, 56,000 MT). Tamil Nadu ranks third with an area of 8, 0000 ha and production of 2, 80,000 MT. Moringa oleifera is the most widely cultivated species of a monogeneric family, the Moringaceae. This plant is native to the Indian subcontinent and has become naturalized in the tropical and subtropical areas around the world. It can grow well in the humid tropics or hot dry lands and can survive in less fertile soils (Anwar et al., 2005) ${ }^{[3]}$. It is a drought-tolerant, fast-growing and multi-purpose and one of the most useful trees due to its medicinal and nutritional properties in world and therefore described as a "miracle tree (Ashfaq et al., 2012) ${ }^{[4]}$. All parts of the Moringa tree are edible and have been consumed so long by humans. The leaves have an extremely high nutrient value. The leaves are rich in minerals like calcium, potassium, zinc, magnesium, iron and copper (Jaffe, 1984) ${ }^{[9]}$.

Vitamins like beta carotene of vitamin A, vitamin B such as folic acid, pyridoxine and nicotinic acid, vitamin $\mathrm{C}, \mathrm{D}$ and $\mathrm{E}$ also present in $M$. oleifera apart from 10 essential amino acids. In fact, moringa leaves is said to provide 7 times more vitamin $\mathrm{C}$ than oranges, 10 times more vitamin A than carrots, 18 times more calcium than milk, 9 times more protein than yoghurt, 15 times more potassium than bananas and 24 times more iron than spinach (Rockwood et al., 2013). The different parts of this plant have analgesic, diuretic, antihypertensive, antispasmodic, antitumor, anticancer, antiulcer, cholesterol lowering effect, hepato protective, and hypoglycemic effect and also effective in skin and mucosal diseases (Guevara et al., 1999) ${ }^{[7]}$. Moringa tree is an effective remedy for malnutrition, especially among infants and nursing mothers. Village women of south western Senegal were trained in the preparation and use of Moringa leaf powder in foods for development of growth and improving overall health in children, pregnant women recovered from anaemia and had babies with higher birth weights and breast-feeding women increased their production of milk (Sambou Diatta 2002) ${ }^{[14]}$. 
Moringa seed oil, also known as Ben oil, is a sweet non sticking, non-drying oil with brilliant yellow colour. It is used as a lubricant for fine machinery such as time pieces because it has little tendency to deteriorate and become rancid and sticky (Ramachandran et al., 1980) ${ }^{[11]}$. It is also useful as vegetable cooking and frying oil. The oil is known for its capacity to absorb and retain volatile substances and is therefore valuable in the perfume industry for stabilizing scents. Considering the above fact, the present study is proposed with the following objectives: To characterize the genotypes based on their biochemical characteristics, to identify promising genotypes with high leaf yield and quality and to determine the level of variability existing among the genotypes

\section{Materials and Methods \\ Materials}

Six moringa ecotypes (Block I) maintained in moringa genetic resources garden of Department of Vegetable Science, Horticultural College and Research Institute (HC\&RI), Tamil Nadu Agricultural University, Periyakulam and another six moringa accessions (Block II) were collected from different districts of Tamil Nadu viz., Theni, Madurai, Karur, Dindigul, Tuticorin and Tirupur through limb cuttings and details of the genotypes used in the present study are listed below.

Table 1: Description of moringa genotypes (Block I)

\begin{tabular}{|c|c|c|}
\hline $\begin{array}{c}\text { Accessions } \\
\text { No. }\end{array}$ & $\begin{array}{c}\text { Name of the } \\
\text { genotype } \\
\text { and Characters }\end{array}$ & Place of collection \\
\hline PKM MO 1 & $\begin{array}{c}\text { Otu Karrumpu } \\
\text { Murungai }\end{array}$ & $\begin{array}{c}\text { Kaveiyampatty- } \\
\text { murungai }\end{array}$ \\
\hline PKM MO 2 & Semmurungai & Kamatchipuram - \\
\hline PKM MO 3 & PKM. 2 & Periyakulam \\
\hline PKM MO 4 & Malaimurungai- 29 & Murugamalai - \\
\hline PKM MO 5 & Medium poded & Cholavanthan \\
\hline PKM MO 6 & Long poded & Warangal \\
\hline Check & Nattumurungai -34 & Kamatchipuram- \\
\hline
\end{tabular}

Table 2: Description of moringa genotypes (Block II)

\begin{tabular}{|c|c|c|}
\hline $\begin{array}{c}\text { Accessions } \\
\text { No. }\end{array}$ & $\begin{array}{c}\text { Name of the genotypes } \\
\text { and characters }\end{array}$ & $\begin{array}{c}\text { Place of } \\
\text { collection }\end{array}$ \\
\hline PKM MO 7 & Nool Murungai & Puthupai \\
\hline PKM MO 8 & Bitter Type & NBPGR \\
\hline PKM MO 9 & Yalpanam Murungai & Valliammalpuram \\
\hline PKM MO 10 & Nattu Murungai & Kadayachapuram \\
\hline PKM MO 11 & Vadipatti Murungai & Kujilampaarai \\
\hline PKM MO 12 & Short Poded & Kadamaligundu \\
\hline
\end{tabular}

The above twelve genotypes along with check Nattumurungai (kamatchipuram) were taken for evaluation.

\section{Observations recorded}

In Block I and block II the observations were recorded in each moringa accessions.

\section{Estimation of biochemical parameters Estimation of Ascorbic acid}

Ascorbic acid was estimated according to the procedure given by (A.O.A.C 1975) ${ }^{[1]}$ and expressed as mg per $100 \mathrm{~g}$ of fresh sample.

\section{Estimation of Crude protein}

Total nitrogen $(\%)=[(\mathrm{ml}$ of standard acid $\mathrm{x} \mathrm{N}$ of standard acid) - (ml of standard $\mathrm{NaOH}-$ C.F.) $x \mathrm{~N}$ of standard $\mathrm{NaOH}]$ x 1.4007 /weight of sample (g). Correction factor (C.F.) = (Titre of standard $\mathrm{NaOH}$ against blank - $\mathrm{ml}$ of standard acid). Protein content was determined by multiplying total nitrogen value with 6.25 (A.O.A.C 1975) ${ }^{[1]}$. Protein $(\%)=$ Total Nitrogen (\%) X 6.25

\section{Estimation of Crude fibre}

Crude fibre of dried leaf powder sample was estimated.

\section{Estimation of Moisture Content (\%)}

The moisture content was determined by taking the weight of fresh leaves and it was dried in oven at to get weight of dry leaves. It was worked out and expressed in percentage.

\section{Estimation of Ca and Mg content}

The calcium and magnesium content of dried leaf powder sample was estimated as per the method described by (Jackson 1973) ${ }^{[8]}$ an expressed in percentage (\%).

\section{Estimation of Potassium (K) Concentrations}

The Flame Photometry method was used to determine the potassium concentrations. The digest was diluted and the potassium emissions measured in air- acetylene flame. A calibration curve of potassium emission against concentration was drawn and compared to that of a standard solution (A.O.A.C 1975) ${ }^{[1]}$.

\section{Determination of Micro nutrient}

Determination of micro nutrient was done by dry ashing and atomic absorption spectrophotometer (AAS), according to (A.O.A.C 1975) ${ }^{[1]}$. The micro nutrient that was determined was iron.

\section{Statistical analysis}

Analysis of variance

Estimation of ANOVA using the mean values of all genotypes to find out the significance of genotypes effect was suggested by (Panse and Sukhatme 1985) ${ }^{[10]}$

\section{Results and Discussion}

Twelve accessions of moringa were evaluated for different morphological and biochemical characters. Observations on morphological, physiological and biochemical characters were studied. Biochemical traits viz., vitamin C (mg/100g), vitamin A $(\mathrm{mg} / 100 \mathrm{~g})$, crude protein $(\%)$, crude fibre $(\%)$, calcium (\%), magnesium (\%), potassium (mg/100g), iron (ppm) were recorded. The per se performance plays an important criterion for discarding the undesirable types, which could be used for any selection programme, for crop improvement. This possesses a better scope of the germplasm to be employed as the potential source and also for selecting the high yielding accessions with all desirable attributes. The results of the present investigation in twelve moringa genotypes showed similarity with the findings of many workers in moringa (Resmi et al., 2006) ${ }^{[12]}$, (Tak and Maurya 2015b) ${ }^{[17]}$ and (Tak and Maurya 2015a) ${ }^{[16]}$. Analysis of different characters revealed that the mean square values among the accessions were positive for all the traits studied under the possibility of exploiting the variation for quality improvement programmes in moringa.

Vitamin $\mathrm{C}$ is essential micro-nutrient required for normal metabolic functions of human body, supplied by fruits and vegetables. According to US standards minimum of $60 \mathrm{mg}$ of ascorbic acid is a daily requirement for human body (Ting 1980) ${ }^{[19]}$. Moringa is a good source of vitamin C yet its use as 
a good source of ascorbic acid is not explored much. The highest vitamin $\mathrm{C}$ was recorded by PKM MO 2 (155.60 $\mathrm{mg} / 100 \mathrm{~g}$ with mean value of $88.48 \mathrm{mg} / 100 \mathrm{~g}$. Similar results were observed by (Sankhyan et al., 2013) ${ }^{[15]}$. The genotypes viz., (PKM MO 9) 145.61, (PKM MO 7) 141.40 and (PKM MO 12) 140.56 were found to be superior in ascorbic acid content. The check nattumurungai (kamatchipuram) showed $69.50(\mathrm{mg} / 100 \mathrm{~g})$ of vitamin C content (Table 3). Vitamin A is a natural antioxidant to inhibit free radicals and very important for improving the immune system. The highest vitamin A was reported in PKM MO 7 (17.40 mg/100g) with mean of $11.9 \mathrm{mg} / 100 \mathrm{~g}$. Similar trend of variation were also reported by (El Sohaimy et al., 2015) ${ }^{[6]}$. The check nattumurungai (kamatchipuram) exhibited $11.5(\mathrm{mg} / 100 \mathrm{~g})$ of $\beta$-carotene content. Among the genotypes, the highest crude fibre content was observed in PKM MO $2(11.43 \%)$ and the mean was 17.44 per cent. The RDA of dietary fibre for adult males and females is 38 and $25 \mathrm{~g} /$ day, respectively (Trumbo et al., 2002) [21], a nutrient of diet that is necessary for digestion and promoting soft stools for effective elimination (Vadivel and Janardhanan 2005) ${ }^{[22]}$. So, the content of fibre in the vegetables can encourage their use in the human diet to fulfill the RDA of fibre. The highest and the lowest crude fibre content was recorded in accessions PKM MO 1 (25.60) and PKM MO 9 (12.40) with a grand mean of 17.44 per cent (Tejaswini et al., 2017). The accession viz., (PKM MO 2)
12.40, (PKM MO 6) 14.40 had lower content of crude fibre. The check nattumurungai (kamatchipuram) had crude fibre content of $20.2 \%$ (Jaffe, 1984) $^{[9]}$.

Crude protein was recorded to be higher in accessions PKM MO $8(33.40 \%)$ followed by PKM MO 4 (32.44 \%) with mean of $26.15 \%$. Similar results were recorded by (Aye and Adegun 2013) ${ }^{[5]}$. The accession PKM MO 8 (33.40\%) exhibited the highest and lowest value of crude protein content. It showed a grand mean value of 26.15 per cent. The check nattumurungai (kamatchipuram) recorded $27.24 \%$ of crude protein content. Minerals are essential for digestion and for optimum productivity. The mineral content of leaf meal varies with location as reported earlier by (Anjorin et al., $2010)^{[2]}$. The calcium content was found to be higher in PKM MO $11(3.62 \%)$. The grand mean value was 2.04 . The check nattumurungai (kamatchipuram) recorded $2.58 \%$ of calcium content. The magnesium content was highest in PKM MO 6 $(0.86 \%)$ followed by PKM MO $12(0.86 \%)$. The magnesium content was observed to range from $0.14-0.95$ per cent. The grand mean value was 0.55 per cent (Ting, 1980) ${ }^{[19]}$. The check Nattumurungai (kamatchipuram) had $0.52 \%$ of magnesium content. Potassium content was recorded higher in genotype PKM MO 3 (3.86 \%), followed by PKM MO 5 $(3.20 \%)$ with mean of $1.20 \%$. The recorded range of potassium was from $0.09-2.73$ percent

Table 3: Mean performance of moringa accessions for leaf characters

\begin{tabular}{|c|c|c|c|c|c|c|c|c|}
\hline Accessions & $\begin{array}{c}\boldsymbol{\beta} \text {-carotene } \\
(\mathbf{m g} / \mathbf{1 0 0 g})\end{array}$ & $\begin{array}{c}\text { Vitamin C } \\
(\mathbf{m g} / \mathbf{1 0 0 g})\end{array}$ & $\begin{array}{c}\text { Crude } \\
\text { fibre }(\boldsymbol{\%})\end{array}$ & $\begin{array}{c}\text { Crude } \\
\text { protein }(\boldsymbol{\%})\end{array}$ & $\begin{array}{c}\text { Potassium } \\
(\boldsymbol{\%})\end{array}$ & $\begin{array}{c}\text { Iron } \\
(\mathbf{p p m})\end{array}$ & $\begin{array}{c}\text { Calcium } \\
(\boldsymbol{\%})\end{array}$ & $\begin{array}{c}\text { Magnesium } \\
(\boldsymbol{\%})\end{array}$ \\
\hline PKM MO 1 & 14.20 & 115.50 & 25.60 & 30.80 & 3.15 & 255 & 3.52 & 0.75 \\
\hline PKM MO 2 & 9.00 & 155.60 & 11.43 & 23.50 & 2.87 & 231 & 3.01 & 0.70 \\
\hline PKM MO 3 & 11.20 & 72.44 & 17.40 & 27.40 & 3.86 & 247 & 2.58 & 0.89 \\
\hline PKM MO 4 & 12.40 & 117.37 & 20.20 & 32.44 & 3.50 & 215 & 1.49 & 0.85 \\
\hline PKM MO 5 & 7.43 & 72.45 & 20.10 & 32.31 & 3.20 & 235 & 3.32 & 0.52 \\
\hline PKM MO 6 & 9.10 & 77.81 & 14.40 & 30.87 & 1.12 & 228 & 1.56 & 0.86 \\
\hline PKM MO 7 & 17.40 & 141.40 & 14.50 & 31.40 & 1.50 & 254 & 1.82 & 0.87 \\
\hline PKM MO 8 & 15.50 & 97.31 & 15.50 & 33.40 & 0.09 & 249 & 1.62 & 0.51 \\
\hline PKM MO 9 & 13.40 & 145.61 & 12.40 & 28.05 & 0.12 & 237 & 2.65 & 0.59 \\
\hline PKM MO 10 & 12.40 & 82.43 & 15.50 & 32.50 & 1.10 & 250 & 3.00 & 0.81 \\
\hline PKM MO 11 & 16.70 & 120.12 & 15.20 & 32.41 & 0.90 & 222 & 3.62 & 0.71 \\
\hline PKM MO 12 & 15.40 & 140.50 & 15.40 & 29.15 & 1.90 & 253 & 2.87 & 0.86 \\
\hline Nattumurungai (Check) & 11.50 & 69.50 & 20.21 & 27.24 & 1.08 & 241 & 2.58 & 0.52 \\
\hline SE (d) & 0.21 & 1.99 & 0.64 & 0.55 & 0.02 & 5.11 & 0.039 & 0.012 \\
\hline CD (0.05\%) & 0.42 & 3.94 & 1.27 & 1.10 & 0.05 & 10.11 & 0.079 & 0.025 \\
\hline
\end{tabular}

The check nattumurungai (kamatchipuram) recorded $1.08 \%$ potassium content (Toma, 2016) ${ }^{[20]}$. The iron content ranged from 210 - $255 \mathrm{ppm}$. The accessions PKM MO 7 (254 ppm) followed by PKM MO 10 (250 ppm) recorded the highest iron content. The highest iron content was observed in PKM MO 7. The grand mean value was $234.65 \mathrm{ppm}$. The check nattumurungai (kamatchipuram) showed $241 \mathrm{ppm}$ of iron content.

\section{Conclusion}

In the present trail, twelve divergent accessions of moringa have been evaluated. The accessions were studied such as crude protein $(\%)$, crude fibre $(\%)$, calcium $(\%)$, magnesium $(\%)$, potassium (\%), Vitamin C (mg/100g), Vitamin A $(\mathrm{mg} / 100 \mathrm{~g})$, iron (ppm) and the observation are recorded. The per se performance plays an important criterion for discarding the undesirable types, which could be used for any selection programme, for crop improvement. This possesses a better scope of the germplasm to be employed as the potential source and also for selecting the high yielding accessions with all desirable attributes. Analysis of different characters recognized that the mean square values among the accessions were positive for all the eight traits studied under the possibility of exploiting the variation for quality improvement programmes in moringa. Leaf yield was also noticed to be higher in genotypes rich in crude protein, calcium, magnesium and potassium. Based on per se performance of the genotypes regarding biochemical traits, the genotypes viz., PKM MO 2 (155.60 mg/100g), PKM MO 9 (145.61 $\mathrm{mg} / 100 \mathrm{~g})$ and PKM MO $12(140.56 \mathrm{mg} / 100 \mathrm{~g})$ revealed the higher vitamin $\mathrm{C}$ content, the genotypes viz., PKM MO 8 (33.40 \%), PKM MO 4 (32.44 \%) and PKM MO 10 (32.50\%) showed highest crude protein content, the genotypes viz., PKM MO 7 (254 ppm), PKM MO 10 (250 ppm) and PKM MO 12 (253 ppm) registered the higher iron content. These genotypes may be utilized for further studies in moringa.

\section{References}

1. AOAC. Official and tentative methods of analysis. Washington D.C., U.S.A. 12th Ed., 1975. 
2. Anjorin, Toba Samuel, Pius Ikokoh, Simon Okolo. Mineral composition of Moringa oleifera leaves, pods and seeds from two regions in Abuja, Nigeria. International Journal of Agriculture Biology. 2010; 12(3):431-434.

3. Anwar, Farooq, Muhammad Ashraf, Muhammad Iqbal Bhanger. Interprovenance variation in the composition of Moringa oleifera oilseeds from Pakistan. Journal of the American Oil Chemists' Society. 2005; 82(1):45-51.

4. Ashfaq M, Shahzad MA Basra, Umair Ashfaq. Moringa: A miracle plant for agro-forestry. Journal of agriculture social sciences. 2012; 8(3).

5. Aye PA, Adegun MK. Chemical composition and some functional properties of Moringa, Leucaena and Gliricidia leaf meals. Agriculture biology journal of North America. 2013; 4(1):71-77.

6. El Sohaimy, Sobhy A, Gamal M Hamad, Sameh E Mohamed, Mohamed H Amar, Rashad R Al-Hindi. Biochemical and functional properties of Moringa oleifera leaves and their potential as a functional food. Global Advanced Research Journal of Agricultural Science, 2015; 4(4):188-199.

7. Guevara, Amelia P, Carolyn Vargas, Hiromu Sakurai, Yasuhiro Fujiwara, Keiji Hashimoto et al. An antitumor promoter from (Moringa oleifera. Lam). Mutation Research / Genetic Toxicology Environmental Mutagenesis. 1999; 440(2):181-188.

8. Jackson ML. Soil Chemical Analysis: Prentic Hall Pvt. Ltd. New Delhi, 1973.

9. Jaffe GM. Handbook of Vitamins. New York: Marcel Dekker, 1984.

10. Panse VG. Genetics of quantitative characters in relation to plant breeding. Indian J. Genet. 1957; 17(2):318-328.

11. Ramachandran C, Peter KV, Gopalakrishnan PK. Drumstick (Moringa oleifera): A multipurpose Indian vegetable. Economic Botany. 1980; 34(3):276-283.

12. Resmi DS, Celine VA, Rajamony L. Variability among drumstick (Moringa oleifera Lam.) accessions from central and southern Kerala. Journal of Tropical Agriculture. 2006; 43:83-85.

13. Rockwood JL, Anderson BG, Casamatta DA. Potential uses of Moringa oleifera and an examination of antibiotic efficacy conferred by M. oleifera seed and leaf extracts using crude extraction techniques available to underserved indigenous populations. International Journal of Phytotherapy Research. 2013; 3(2):61-71.

14. Sambou Diatta B. Supplementation for pregnant and breast-feeding women with Moringa oleifera powder (Senegal), 2002.

15. Sankhyan, Nidhi, Anshul Sharma, Chandrika Attri Seth, Anjali Chauhan, Kulshrestha S. Determination and comparison of Vitamin C content from Moringa oleifera by different methods. International Journal of Agriculture Science Research. 2013; 3(2):67-70.

16. Tak S, Maurya IB. Genetic diversity of Moringa oleifera Lam. in Rajasthan, India. I International Symposium on Moringa 1158, 2015a.

17. Tak S, Maurya IB. Genetic variability in drumstick genotypes, 2015 b.

18. Tejaswini, N, K Ravinder Reddy, P Saidaiah, Ramesh T. Correlation and Path Coefficient Analysis in Vegetable Amaranth (Amaranthus tricolor L.) Genotypes. Int. J Curr. Microbiol. App. Sci. 2017; 6(6):2977-2996.

19. Ting SV. Nutrients and nutrition of citrus fruits. Citrus nutrition quality, 1980, 1-23.
20. Tomar, Rukam S, Kulkarni GU, Kakade DK. Genetic analysis in muskmelon (Cucumis melo L.). Journal of Horticultural Science. 2016; 3(2):112- 118.

21. Trumbo, Paula, Sandra Schlicker, Allison A Yates, Mary Poos. Dietary reference intakes for energy, carbohdrate, fiber, fat, fatty acids, cholesterol, protein and amino acids. Journal of the Academy of Nutrition Dietetics. 2002; 102(11): 1621.

22. Vadivel V, Janardhanan K. Nutritional and antinutritional characteristics of seven South Indian wild legumes. Plant Foods for Human Nutrition. 2005; 60(2):69-7. 